\title{
Analysis of Quality Control of Avtur Fuel in The Storage Tank at PT. XYZ on The Value of Electrical Conductivity During Covid-
} 19

\author{
Sasmita*, $S$ Rohana, and $A C$ Dewi \\ Industrial Engineering, Faculty of Engineering, Universitas Pembangunan Nasional Veteran Jakarta, Indonesia
}

\begin{abstract}
In the process of receiving Avtur/Jet A-1 by PT. XYZ, the product received often does not meet the specification standard on the Electrical Conductivity. To overcome, doping Stadis 450 was carried out which could increase the Conductivity Unit. In the doping process, there are inefficiencies in the use of the Stadis 450 . The result obtained indicates that all the final CUs are not following the CU target with an average difference of $41.67 \mathrm{pS} / \mathrm{m}$. Also, the current pandemic conditions have resulted in the stockpiling of Avtur/Jet A-1 in the stockpile tank for a longer time. So that PT. XYZ increases the CU target in the doping process so the CU value can be appropriate when used. Determination of CU targets in trial and error without standard considerations will lead to waste in the use of Stadis 450 and increase the potential for discrepancies that occur in the doping process. To minimize, a reduction in CU Avtur/Jet A-1 is calculated as one of the suggestions in considering the $\mathrm{CU}$ target to be achieved. The result of the observed decline based on hoarding data showed that there was an average decline of $6.4646 \mathrm{pS} / \mathrm{m}$ per day.
\end{abstract}

Keywords: Quality Control, Avtur/Jet A-1, Electrical Conductivity, Stadis 450

\section{Introduction}

PT. XYZ is one of the companies included in the downstream business sector within the aviation fuel business scope. PT. XYZ has the role and responsibility to receive, store and distribute Avtur/Jet A-1 received from Tankers to Airports. To carry out activities related to its role, PT. XYZ has several supporting facilities such as a Storage Tank (Receiving and Distribution) with a total capacity that reaches $111,000 \mathrm{KL}$, Micro Filter which serves to prevent Avtur/Jet A-1 contamination with contaminants, Water Filter Separator which serves to separate Avtur/Jet A-1 from water, and so other supporting facilities.

During the Covid-19 pandemic, the amount of fuel needed for flights at Airports decreased. It is due to government regulations to impose flight restrictions to prevent the spread of the virus. The decrease in the amount of fuel needed at the Airport has an impact on the business processes at PT. XYZ. The decrease requires the fuel to be in the storage tank to be longer. The storage duration of Avtur/Jet A-1 corresponds to the change in quality related to the characteristics of the fuel. One of the changes in quality that occurs is due to a decrease in the value of Electrical Conductivity, which is the ability of a substance to conduct electric current. This ability plays a role in circulating electron charges on a material surface to prevent static electricity that has the potential to cause a fire.

To minimize risk, PT. XYZ adds additives in the form of Static Dissipator (Stadis) 450, pure organic compounds, and serves to increase the value of the Electrical Conductivity (Conductivity Unit) to reduce the risk of fire. However, during the pandemic, the average monthly usage of Stadis 450 was increased from $1.709 \mathrm{ccs}$ to $5.428 \mathrm{ccs}$. An increase in the volume of use from Stadis 450 also impacts handling costs. For this reason, the process of adding Stadis 450 needs to be optimized to minimize waste and other losses.

In determining the proposed improvement to obtain optimal volume, it is necessary to gradually identify the causes and impacts associated with the Avtur/Jet A-1 characteristics, and in the process of adding Stadis 450, this can be done with a Six Sigma approach. In this research, the Six Sigma approach is carried out using the DMAIC method, which is a method consisting of the stages of Define, Measure, Analyze, Improve, and Control. The final goal to be achieved in this research is to determine the optimal volume of Stadis 450 which can be added to Avtur/Jet A-1 to increase the value of Electrical Conductivity.

\footnotetext{
* Corresponding author: sasmita0616@gmail.com
} 


\section{Research Methods}

\subsection{Preparation}

This research was conducted because based on the observations made it was found that there was a decrease in demand for Avtur/Jet A-1 fuel at PT. XYZ during a pandemic which then has an impact on changing fuel characteristics. Based on the information obtained, one of the contributing factors is a decrease in the value of Electrical Conductivity. So that the addition of Stadis 450 was carried out to increase this value. This addition needs to be done optimally so that there is no waste and loss. Therefore, the main problem examined in this research is to determine the optimal volume in the addition of Stadis 450 to Avtur/Jet A-1 fuel which has decreased the value of Electrical Conductivity.

\subsection{Data Collection}

The data used in this study are divided into 2 types of data:

1. Primary Data is data obtained from PT. XYZ directly either through observation or interviews with related parties. The primary data in this research are data on the value of the day of coverage, defective products/products that do not meet specifications, Doping Stadis 450, Conductivity Unit (CU), Density, and so on.

2. Secondary Data is data or information obtained indirectly. In this research, data were obtained from the results of previous research which could be sourced from PT. XYZ itself, books, journals, websites, and other valid sources.

\subsection{Data Processing}

The data that has been collected is then processed so that it can be analyzed and conclusions can be drawn. In data processing, the stages carried out include analysis of the business process flow at PT. XYZ is conducted to obtain information and identify how the business process takes place. In addition, data processing is also carried out by following the stages of DMAIC analysis on Six Sigma to facilitate analysis and concluding, as well as using supporting methods to make improvements in all aspects of the company.

\subsection{Final Stage}

This stage consists of drawing conclusions based on the results of processing and analysis that have been carried out in the previous stage. In addition, this stage also contains constructive suggestions for both companies and researchers, so that it is hoped that improvements and development can be carried out in further research.

\section{Result and Discussion}

\subsection{Process Bussiness Flow}

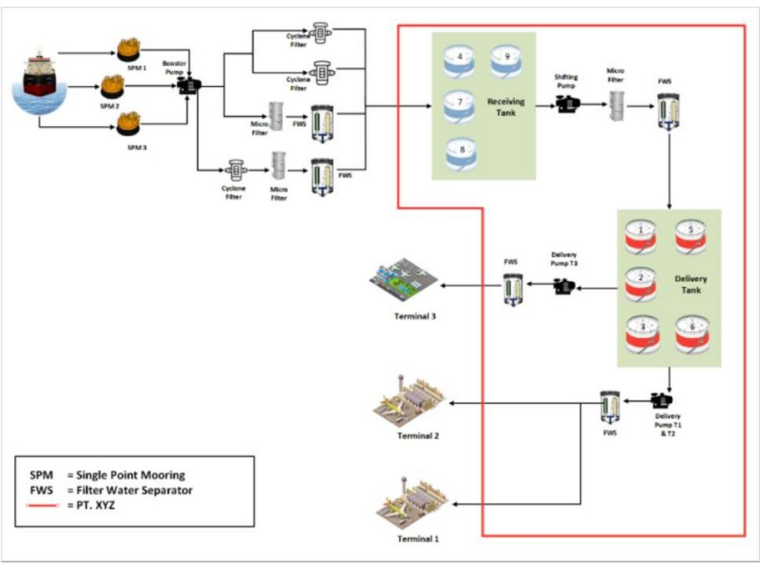

Fig. 1. Process Business Flow.

In the scope of the aviation fuel business, PT. XYZ is included in the downstream business which includes the management, marketing, and trading, as well as the distribution of the fuel itself. In the downstream business process, crude oil that has been purchased is then processed into several products at the Refinery Unit (RU). The products produced include light (premium, pertamax, and pertalite), medium distillate (kerosene, aviation fuel, and diesel), heavy (fuel oil, asphalt, and residue), petrochemicals, and LPG. The processed product is then distributed using a specific distribution system so that it can be utilized by various types of consumers according to the target fuel use.

PT. XYZ's role is to receive, store and distribute Avtur/Jet A-1 received from RU through tankers and pipeline distribution systems to meet fuel needs at the Airport. PT. XYZ is also responsible for ensuring the quality of Avtur/Jet A-1 remains within standard limits so that the products delivered are of the best quality

\subsection{Define}

\subsubsection{SIPOC Diagram}

The elements below (Table 2) show the relationship between Suppliers, Inputs, Processes, Outputs, and Customers in a business process at PT. XYZ.

In the process of distributing Avtur/Jet A-1 to PT. $\mathrm{XYZ}$, received products often have substandard product quality based on the cause of certain defects. So in this case the researchers suspect that RU as a supplier plays a role in causing quality that does not meet the standards of this product. The following is a SIPOC diagram showing the activities at PT. XYZ. 
Table 1. SIPOC Diagram.

\begin{tabular}{|c|c|c|c|c|}
\hline Supplier & Input & Process & Output & Customer \\
\hline $\begin{array}{ll}\text { - } & \text { Refinery Unit } \\
\text { IV } \\
\text { - } & \text { Refinery Unit II }\end{array}$ & Avtur/Jet A-1 & $\begin{array}{l}\text { Store and maintain the quality } \\
\text { of avtur: } \\
\text { - Increase the value of } \\
\text { Conductivity Unit } \\
\text { - Ensure the Density is within } \\
\text { standard limits } \\
\text { - Ensure the Temperature is } \\
\text { under the Flash Point } \\
\text { - Ensure that Avtur/Jet A-1 is } \\
\text { not contaminated with } \\
\text { contaminants } \\
\text { - Saparate Avtur/Jet A-1 } \\
\text { from water }\end{array}$ & $\begin{array}{l}\text { Avtur/Jet A-1 that } \\
\text { according to } \\
\text { standard } \\
\text { specifications }\end{array}$ & $\begin{array}{ll}\text { - } & \text { Airport } \\
\text { - } & \text { Aircraft } \\
\text { maintenance } \\
\text { company }\end{array}$ \\
\hline
\end{tabular}

\subsubsection{Control To Quality (CTQ)}

A product is categorized as a defective product or has decreased in quality if the specifications shown from the inspection results do not comply with the standard criteria. The inspection was carried out at the receiving tank, where the Avtur/Jet A-1 had passed the quality control process. In this study, 5 types of disability criteria were found which are shown in the following table:

Table 2. Control To Quality.

\begin{tabular}{|c|c|c|}
\hline No. & Type of Defect & Effect of Product Defect \\
\hline 1 & $\begin{array}{l}\text { Low the value of } \\
\text { Conductivity Unit }\end{array}$ & $\begin{array}{l}\text { Reduce the Electrical } \\
\text { Conductivity } \\
\text { Avtur/Jet A-1, thereby } \\
\text { increasing the potential } \\
\text { of static electricity } \\
\text { occurring }\end{array}$ \\
\hline 2 & $\begin{array}{l}\text { Density beyond } \\
\text { the standard limit }\end{array}$ & Potential contamination \\
\hline 3 & $\begin{array}{l}\text { Temperature } \\
\text { above the Flash } \\
\text { Point }\end{array}$ & Potential fire \\
\hline 4 & $\begin{array}{l}\text { Contaminated with } \\
\text { contaminants }\end{array}$ & $\begin{array}{l}\text { Damage storage tanks } \\
\text { and fuel tanks in aircraft, } \\
\text { eliminating separation } \\
\text { ability, and reducing the } \\
\text { surface tension between } \\
\text { water and Avtur/Jet A-1. }\end{array}$ \\
\hline 5 & Contains water & $\begin{array}{l}\text { The water in Avtur/Jet } \\
\text { A-1 will freeze at a } \\
\text { certain temperature and } \\
\text { voltage so that it will } \\
\text { clog the filter pipes and } \\
\text { the combustion pipes on } \\
\text { the aircraft. }\end{array}$ \\
\hline
\end{tabular}

Based on the information submitted by the Receiving Storage and Distribution division as well as the data recapitulation that has been done, it can be seen that most of the disability criteria are still under control. This is because of the existing facilities at PT. XYZ can work well. Though, defects may still be found for defective products caused by a low Conductivity Unit (CU) value. However, only Avtur/Jet A-1 in the receiving tank had sub-standard CU values, with the CU values for tanks 104, 107, 108, and 109 being 59.13, $51.17,41.40$, and 53.23, respectively. Because of PT. $\mathrm{XYZ}$ becomes the supply point for similar companies, so the minimum $\mathrm{CU}$ value set is $80 \mathrm{pS} / \mathrm{m}$.

\subsubsection{Avtur/Jet A-1 stockpile relationship with increased doping volume.}

Hoarding activities can affect the quality of Avtur / Jet A-1, this quality change can be caused either due to the nature of Avtur/Jet A-1 itself or due to environmental factors. One of the efforts to maintain the quality of Avtur/Jet A-1 is by doping Stadis 450. Doping Stadis 450 is an activity to add Static Dissipator (Stadis) 450 to Avtur/Jet A-1 to increase the value of the Conductivity Unit (CU). According to information from the Receiving Storage and Delivery division of PT. XYZ, Doping Stadis 450 additions increased during the pandemic. This happened in line with the increase in the specified target CU value. Under normal conditions, the target $\mathrm{CU}$ value is $80 \mathrm{pS} / \mathrm{m}$. Meanwhile, currently, the CU target could reach $200 \mathrm{pS} / \mathrm{m}$. The increase in the CU target was carried out by considering the decline in sales and hoarding that had occurred.

\subsection{Measure}

\subsubsection{Avtur/Jet A-1 volume stockpile and usage of Stadis 450}

The recapitulation of the volume of use of Stadis 450 was carried out based on recording data in the form of injection activity worksheets (doping). This sheet provides various information regarding Avtur/Jet A-1 
volume in the storage tank, the Stadis 450 pure volumes used for doping, Conductivity Unit (CU), the Stadis 450 concentrations in Avtur/Jet A-1, and so on. The volume usage of this Doping Stadis 450 is then recapitulated to get the total and average usage per month. So that the following data is obtained:

Table 3. Avtur/Jet A-1 volume stockpile and usage of Stadis 450.

\begin{tabular}{cccc}
\hline & & \multicolumn{2}{c}{ Volume } \\
\cline { 3 - 4 } No. & Month & Product (L) & $\begin{array}{c}\text { Stadis } \\
(\mathrm{cc})\end{array}$ \\
\hline 1 & March & $257,115,818$ & 20,900 \\
2 & April & $132,460,139$ & 14,200 \\
3 & May & $54,189,099$ & 6,000 \\
4 & June & $110,134,793$ & 34,000 \\
5 & July & $110,423,584$ & 36,000 \\
6 & August & $137,855,675$ & 41,500 \\
7 & September & $181,239,601$ & 45,431 \\
8 & October & $233,386,475$ & 48,822 \\
9 & November & $225,245,441$ & 67,682 \\
10 & December & $290,601,503$ & 70,880 \\
& Total & $1,732,652,128$ & 385,415 \\
& Average & $173,265,213$ & 38,542 \\
\hline
\end{tabular}

\subsubsection{Data Normality Test}

The data normality test is carried out to determine the distribution of data in a certain population so that it can be seen whether the data used is normally distributed or not.

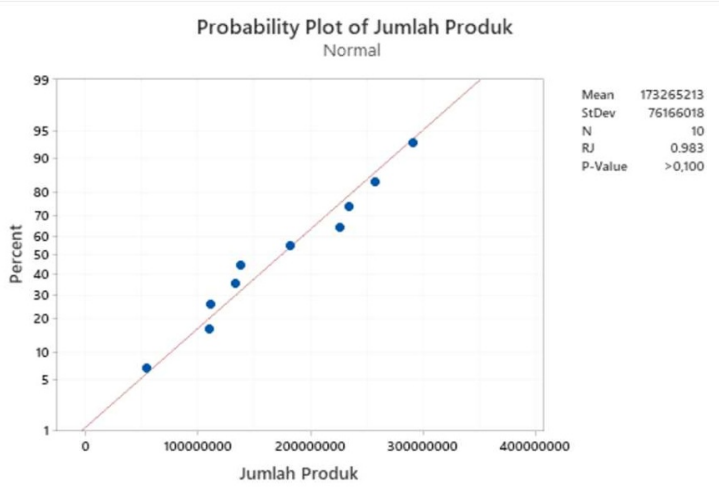

Fig. 2. Data Normality Test of Total Product (volume).

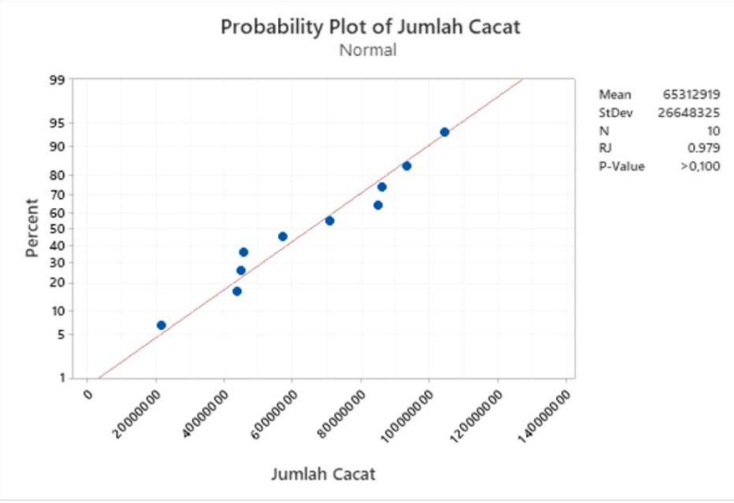

Fig. 3. Data Normality Test of Total Defect (volume).

Based on the graph above, it can be concluded that the P-Value generated for the data on the number of products and the number of defects is $>0.100$. Where the P-Value $>\alpha$ or $0.100>0.05$, so the data is normally distributed.

\subsubsection{P Control Chart}

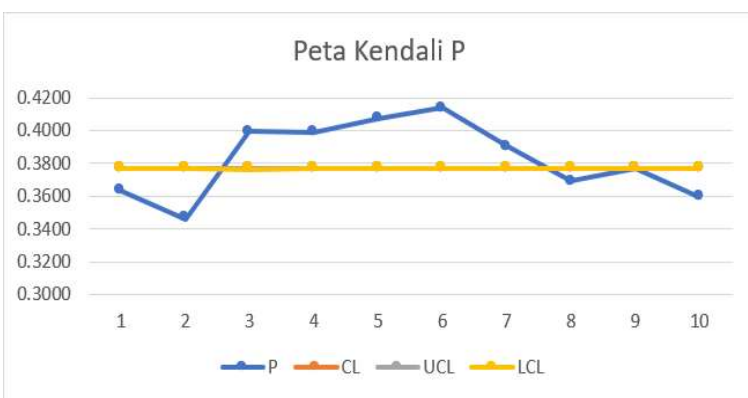

Fig. 4. P Control Chart.

Based on the calculation results and control chart above, it can be seen that all data is outside the control limit. The control boundary distance from the mean value is very small, for example, the distance between UCL and CL is only 0.000000010608 , while the LCL value with $\mathrm{CL}$ is much smaller. The out-of-control data from the control limit is due to the business processes that occur at PT. XYZ, Avtur/Jet A-1 received from the Refinery Unit (RU) had a $\mathrm{CU}$ value that was below the $\mathrm{CU}$ acceptance standard $(80 \mathrm{pS} / \mathrm{m})$. So it can be said that part of Avtur/Jet A-1 was received by PT. XYZ from RU experienced a decrease in quality due to a decrease in the value of $\mathrm{CU}$.

\subsubsection{Defect Per Opportunity and Defect Per Million Opportunities}

Based on the CTQ, the failure criteria used to perform DPO calculations are based on the Conductivity Unit (CU). The calculations to get the DPMO value and the sigma value are as follows:

1. Defect Per Opportunity (DPO)

$$
D P O=\frac{93,306,993}{257,115,818 \times 1}=0.3629
$$


2. Defect Per Million Opportunities (DPMO)

$$
\begin{gathered}
D P O=\frac{93,306,993}{257,115,818 \times 1} \times 1,000,000 \\
=362,899
\end{gathered}
$$

3. DPMO Conversion to Sigma Value

$$
\begin{aligned}
\text { Sigma Value }= & \text { NORMINV }[1,000,000 \\
& \left.-\frac{362,899}{1,000,000}\right]+1.5
\end{aligned}
$$

\begin{tabular}{|c|c|c|c|c|c|c|}
\hline No. & Month & $\begin{array}{l}\text { Number of } \\
\text { Product (L) }\end{array}$ & $\begin{array}{l}\text { Number of } \\
\text { Defect (L) }\end{array}$ & DPO & DPMO & Sigma Value \\
\hline 1 & March & $257,115,818$ & $93,306,993$ & 0.3629 & 362,899 & 1.8507 \\
\hline 2 & April & $132,460,139$ & $45,832,055$ & 0.3460 & 346,007 & 1.8961 \\
\hline 3 & May & $54,189,099$ & $21,656,996$ & 0.3997 & 399,656 & 1.7542 \\
\hline 4 & June & $110,134,793$ & $43,933,956$ & 0.3989 & 398,911 & 1.7562 \\
\hline 5 & July & $110,423,584$ & $44,997,189$ & 0.4075 & 407,497 & 1.7340 \\
\hline 6 & Aug & $137,855,675$ & $57,055,798$ & 0.4139 & 413,881 & 1.7176 \\
\hline 7 & Sept & $181,239,601$ & $70,723,662$ & 0.3902 & 390,222 & 1.7787 \\
\hline 8 & Oct & $233,386,475$ & $86,228,566$ & 0.3695 & 369,467 & 1.8333 \\
\hline 9 & Nov & $225,245,441$ & $84,934,035$ & 0.3771 & 377,074 & 1.8132 \\
\hline 10 & Dec & $290,601,503$ & $104,459,944$ & 0.3595 & 359,462 & 1.8599 \\
\hline \multicolumn{2}{|c|}{ Total } & $1,732,652,128$ & $653,129,194$ & 0.3770 & $3,825,076$ & 17.9939 \\
\hline \multicolumn{2}{|c|}{ Average } & $173,265,213$ & $65,312,919$ & 0.3770 & 382,508 & 1.7994 \\
\hline
\end{tabular}

Table 4. Recapitulation of DPO, DPMO, and Sigma Value.

Based on the results of the recapitulation table above, it shows that the average DPO and DPMO produced are 0.3770 and 382.508 respectively and are at a sigma value of 1.7994 or 1.8 .

\subsection{Analyze}

\subsubsection{Doping Static Dissipator (Stadis) 450.}

Based on Control To Quality (CTQ) at the define stage and the results of the DPMO calculation at the measurement stage, efforts were made to overcome the
Avtur/Jet A-1 defect caused by low CU values. Efforts to add additives in the form of Doping Stadis 450 continue to be made to increase the ability of Avtur/Jet A-1 to conduct electric current.

The total Avtur/Jet A-1 that underwent Doping Stadis 450 was $653,129,194 \mathrm{~L}$ with an average per month of $65,312,919 \mathrm{~L}$. To increase the CU of Avtur/Jet A-1, a Stadis 450 of $385,415 \mathrm{cc}$ is needed or the equivalent of $350,727.65$ grams with a monthly average requirement of $38,542 \mathrm{cc}$ or the equivalent of $35,073.22$

\begin{tabular}{|c|c|c|c|c|c|c|c|}
\hline \multirow[b]{2}{*}{ Month } & \multicolumn{3}{|c|}{ Volume } & \multicolumn{3}{|c|}{$\mathrm{CU}(\mathrm{pS} / \mathrm{m})$} & \multirow{2}{*}{$\begin{array}{c}\text { Concentration } \\
(\mathrm{mg} / \mathrm{L})\end{array}$} \\
\hline & Product (L) & $\begin{array}{c}\text { Product } \\
\text { Doping (L) }\end{array}$ & Stadis (cc) & Current & Target & Final & \\
\hline March & $257,115,818$ & $93,306,993$ & 20,900 & 47 & 99 & 90 & 0.2273 \\
\hline April & $132,460,139$ & $45,832,055$ & 14,200 & 57 & 123 & 103 & 0.3014 \\
\hline May & $54,189,099$ & $21,656,996$ & 6,000 & 48 & 110 & 79 & 0.2835 \\
\hline June & $110,134,793$ & $43,933,956$ & 34,000 & 39 & 206 & 154 & 0.8118 \\
\hline July & $110,423,584$ & $44,997,189$ & 36,000 & 39 & 203 & 220 & 0.8038 \\
\hline Aug & $137,855,675$ & $57,055,798$ & 41,500 & 46 & 196 & 218 & 0.7246 \\
\hline Sept & $181,239,601$ & $70,723,662$ & 45,431 & 46 & 188 & 275 & 0.6349 \\
\hline Oct & $233,386,475$ & $86,228,566$ & 48,822 & 57 & 185 & 147 & 0.5704 \\
\hline
\end{tabular}
grams. The recapitulation of Doping Stadis 450 is shown in the following table :

Table 5. Recapitulation of Doping Stadis 450 (a). 
Table 6. Recapitulation of Doping Stadis 450 (b).

\begin{tabular}{cccccccc}
\hline \multirow{2}{*}{ Month } & \multicolumn{3}{c}{ Volume } & \multicolumn{3}{c}{ CU (pS/m) } & $\begin{array}{c}\text { Concentration } \\
(\mathrm{mg} / \mathrm{L})\end{array}$ \\
\cline { 2 - 6 } & Product (L) & $\begin{array}{c}\text { Product } \\
\text { Doping (L) }\end{array}$ & Stadis (cc) & Current & Target & Final & 0.7116 \\
\hline Nov & $225,245,441$ & $84,934,035$ & 67,682 & 41 & 198 & 200 & 0.6316 \\
Dec & $290,601,503$ & $104,459,944$ & 70,880 & 53 & 186 & 162 & 5.7008 \\
Total & $1,732,652,128$ & $653,129,194$ & 385,415 & 473 & 1,694 & 1,648 & 0.5701 \\
Average & $173,265,213$ & $65,312,919$ & 38,542 & 47 & 169 & 165 & \\
\hline
\end{tabular}

\subsubsection{Correlation Test}

This test is carried out to determine whether there is an increase in storage time whether this can affect the addition of Doping Stadis 450. The following are the calculation results obtained from the correlation test:

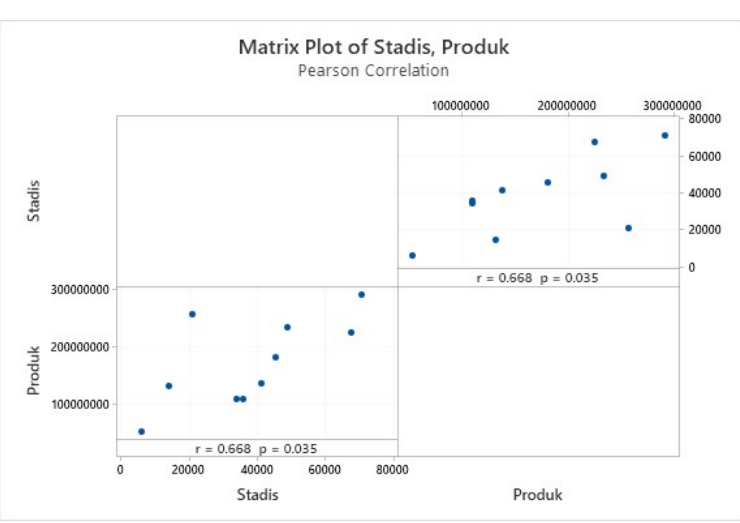

Fig. 5. Correlation Test Graph.

The resulting P-Value is 0.035 . P-Value $<\alpha$ or 0.035 $<0.05$, so that there is a significant relationship between the stockpiling of Avtur/Jet A-1 and the Doping Stadis 450 process. For the Coefficient Correlation value, it is 0.668 . Where it is positive, it means that the relationship between hoarding and doping statistics shows the same direction. If viewed from the point of view of the strength of the correlation, the resulting value is in the limit of $0.6 \leq|\mathrm{r}| \leq 0.8$ which means that both of them have a strong relationship.

\subsubsection{Fishbone Diagram}

In the Doping Stadis 450 process, process inefficiencies were found, which was indicated by a mismatch between the CU target value and the resulting final value. The mismatch that occurs can become waste (waste) using Stadis 450 so that the resulting CU value is not optimal.

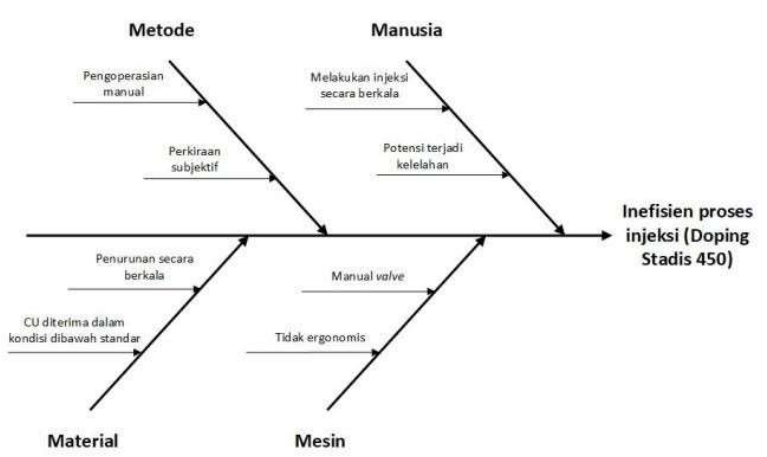

Fig. 6. Fishbone Diagram of Doping Stadis 450.

The diagram above shows the cause and effect that occurs in the Doping Stadis 450 process in several factors. From these causes, some can be minimized if PT. XYZ replaces the machine that was previously an automatic machine currently planned by PT. XYZ. However, some of the causes, such as targeting that still uses estimates and material properties that can decrease periodically, still require other solutions so that plans to minimize process inefficiencies can run well.

\subsection{Improve}

\subsubsection{Decrease of Conductivity Unit (CU)}

The determination of the reduction in the value of $\mathrm{CU}$ was carried out based on the consideration of the absence of transfer activity from the receiving tank and the transfer of Avtur/Jet A-1 to the airport (the tank must be idle). The process of calculating this reduction is carried out by using the $\mathrm{CU}$ value in the sales tank, this is done so that the resulting CU value can last during the stockpiling period that occurs in the sales tank. Determination of $\mathrm{CU}$ reduction, obtained from the difference in $\mathrm{CU}$ value from routine examinations. Based on the calculations that have been made, the average reduction in the value of $\mathrm{CU}$ in the sales tank based on the CU condition data in the stockpile is 6.4646 $\mathrm{pS} / \mathrm{m}$. The results of these calculations can then be used by Receipt and Storage officers to determine the CU target before committing Doping Stadis 450.

\subsubsection{Doping Stadis 450 Stage}

Based on the causes of process inefficiency in the Fishbone Diagram, the determination of CU targets is 
still carried out based on estimates without standard references. Therefore, in determining the CU target, a proposal is made by considering the average amount of $\mathrm{CU}$ reduction. So that the Doping Stadis 450 stages can be carried out as follows:

1. Calculation of the combined $\mathrm{CU}$ value

$C U \mathrm{X}=\frac{(C U A \times \operatorname{Vol} A)+(C U B \times \operatorname{Vol} B)}{\operatorname{Vol} A \times \operatorname{Vol} B}$

Combined CU is the CU obtained when Avtur/Jet A1 in the sales tank (tank A) is mixed with Avtur/Jet A-1 in receiving tank (tank B) without adding Stadis 450. If the resulting value meets the standard, then Avtur/Jet A-1 does not need to go through the injection process (Doping Stadis 450). However, if the resulting $\mathrm{CU}$ value is still below the standard, then Doping Stadis 450 is required.

2. Determination of the average $\mathrm{CU}$

Based on the results of calculations that have been done, the average reduction in $\mathrm{CU}$ value in the stockpiling process is $6.4646 \mathrm{pS} / \mathrm{m}$. This value is then multiplied by the estimated hoarding that occurs, for example, if it is estimated that there will be hoarding for 1 week, 2 weeks, and 3 weeks, then the average reduction in $\mathrm{CU}$ value is $45.2522 \mathrm{pS} / \mathrm{m}$, $90.5044 \mathrm{pS} / \mathrm{m}$, and $135.757 \mathrm{pS} / \mathrm{m}$.

3. Determination of the $\mathrm{CU}$ targets

Based on the average reduction in $\mathrm{CU}$ value that has been obtained, the determination of the target $\mathrm{CU}$ value can be obtained by summing the CU target under normal conditions $(80 \mathrm{pS} / \mathrm{m})$ with the average reduction based on estimated stockpiling. Thus, the expected CU targets for the 1 week, 2 weeks, and 3 weeks stockpile estimates are $126 \mathrm{pS} / \mathrm{m}, 171 \mathrm{pS} / \mathrm{m}$, and $216 \mathrm{pS} / \mathrm{m}$, respectively.

4. Determination of Stadis Mix concentration

Concent. $=\frac{\text { CU Target }- \text { Combined CU }}{200}$

Stadis Mix is a solution or a mixture of pure 450

Stadis with Avtur/Jet A-1. This mixing process is carried out by dissolving 50 grams of pure 450 Stadis into $1 \mathrm{~L}$ Avtur/Jet A1 to produce 1L Stadis Mix. The denominator (200) is obtained from the terms of the relationship Stadis 450 in Avtur/Jet A-1. Where giving Doping Stadis 450 with a concentration of 1 $\mathrm{mg} / \mathrm{L}$ will increase the CU value by $200 \mathrm{pS} / \mathrm{m}$.

5. Determination of the Avtur/Jet A-1 transfer volume

Volume $t f=$ Receive tank volume - Ampafabel volume

Avtur/Jet A-1 in the receiving tank is not completely transferred or transferred to the sales tank. The transfer volume takes into account the volume of Avtur/Jet A-1 in the sales tank and the ampafable volume, which is the amount of Avtur/Jet A-1 that cannot be moved to avoid emptying the tank.

6. Determination of the pure Stadis 450

Volume Stadis $450=$ Consentration $\times$ Volume $t f$

After knowing the total volume of pure Stadis 450, then the Doping Stadis 450 can then be carried out with an injection system during the transfer process from the receiving tank to the sales tank using an injection machine.

\subsubsection{The inefficiency of the CU target with the final CU value at Doping Stadis 450}

The inefficiency of this value can be wasteful in using the Stadis 450, causing the process to be inefficient and the Doping Stadis 450 is not optimal. For this, calculations are carried out to determine the mismatch that has occurred. The calculation is done by calculating the difference between the target $\mathrm{CU}$ and the resulting final $\mathrm{CU}$ value. In addition, the calculation of the pure Stadis 450 requirement is also carried out, if the target determination uses the current $\mathrm{CU}$ final value, with the assumption that there is no difference between the CU target and the final achieved value as follows:

Table 7. Recapitulation of Inefficiency of Doping Stadis 450.

\begin{tabular}{|c|c|c|c|c|c|c|c|c|}
\hline \multirow{2}{*}{$\begin{array}{l}\text { Stadis } \\
450\end{array}$} & \multicolumn{3}{|c|}{$\mathrm{CU}(\mathrm{pS} / \mathrm{m})$} & \multirow{2}{*}{$\begin{array}{l}\text { Consentration } \\
(\mathrm{mg} / \mathrm{L})\end{array}$} & \multicolumn{2}{|c|}{$\begin{array}{c}\text { Ineficiency CU } \\
(\mathrm{pS} / \mathrm{m})\end{array}$} & \multirow{2}{*}{$\begin{array}{l}\text { Concentration of } \\
\text { Ineficiency } \\
(\mathrm{mg} / \mathrm{L})\end{array}$} & \multirow{2}{*}{$\begin{array}{l}\text { Vol. Stadis } \\
\text { of } \\
\text { Ineficiency } \\
\text { (cc) }\end{array}$} \\
\hline & Current & Target & Final & & Less & More & & \\
\hline \multicolumn{9}{|c|}{ Total } \\
\hline 385,415 & 3,401 & 12,065 & 11,743 & 40 & $-1,642$ & 1,311 & 42 & 395,560 \\
\hline \multicolumn{9}{|c|}{ Average } \\
\hline $5,428.38$ & 47.90 & 169.27 & 165.27 & 0.57 & -41.05 & 42.29 & 0.59 & 5,571 \\
\hline \multicolumn{5}{|c|}{ Average of Inefficiency CU } & & & 41.67 & \\
\hline
\end{tabular}


The results obtained indicate that the average difference between the target $\mathrm{CU}$ value and the final $\mathrm{CU}$ value, whether it does not reach the target or exceeds the target, is $41.67 \mathrm{pS} / \mathrm{m}$. Meanwhile, if the doping process is carried out following the final $\mathrm{CU}$ value, the average Stadis 450 concentration in Avtur/Jet A-1 becomes 0.59 $\mathrm{mg} / \mathrm{L}$ from the previous $0.57 \mathrm{mg} / \mathrm{L}$. The increase in this concentration is in line with the increasing demand for Stadis 450 .

\subsection{Cost Requirement for Doping Stadis $\mathbf{4 5 0}$}

Based on information according to the Receiving and Storage officer, the need for a stationary 450 under normal conditions in 1 month is estimated to be 1 pail ( $22 \mathrm{~kg}$ or the equivalent of $24.176 \mathrm{cc}$ ). Increasing the use of Stadis 450 today has the impact of increasing costs incurred. The cost incurred for 1 pail Stadis 450 is Rp. $32,230,000$. So, based on the results of the nonconformity calculations that have been carried out, the following results are obtained:

Table 8. Cost Requirement for Doping Stadis 450.

\begin{tabular}{ccccc}
\hline \multicolumn{5}{c}{ The total cost of Stadis } \\
\hline Month & Target & Final & Less & More \\
\hline March & $27,862,835$ & $26,187,907$ & $-4,777,338$ & $3,102,410$ \\
April & $18,930,730$ & $13,695,915$ & $-5,234,815$ & 0 \\
May & $7,998,900$ & $4,547,786$ & $-3,451,114$ & 0 \\
June & $45,327,100$ & $33,379,946$ & $-12,721,404$ & 774,250 \\
July & $47,993,400$ & $54,316,242$ & $-1,171,665$ & $7,494,507$ \\
August & $55,325,725$ & $65,526,018$ & $-1,620,667$ & $11,820,960$ \\
September & $60,566,338$ & $107,281,201$ & 0 & $46,714,864$ \\
October & $65,087,049$ & $50,503,186$ & $-22,145,547$ & $7,561,684$ \\
November & $90,230,258$ & $94,992,061$ & $-10,042,755$ & $14,804,558$ \\
December & $94,493,672$ & $76,910,639$ & $-21,181,180$ & $3,598,147$ \\
Total & $513,816,007$ & $527,340,901$ & $-82.346,487$ & $95,871,381$ \\
Average & $51,381,601$ & $52,734,090$ & $-9,149,610$ & $11,983,923$ \\
\hline
\end{tabular}

The table above shows that the current total cost of using Stadis 450 is Rp. 513,816,007. Meanwhile, the "Final" column shows if PT. XYZ performs strategic doping with the target $\mathrm{CU}$ value following the current final CU value, and the CU results are assumed to be fulfilled. Then the total cost incurred is $\mathrm{Rp}$. $527,340,901$. The total loss suffered by the company due to failure to reach the target value of $\mathrm{CU}$ was $\mathrm{Rp}$. $82,346,487$. While the total profit that the company gets due to these conditions is Rp. 95,871,381. So if only seen from the addition of Stadis 450 as a whole, then PT. $\mathrm{XYZ}$ benefits from the cost of using the Stadis 450 . This is due to differences in profit and loss at PT. XYZ generates a profit of Rp. 13,524,894. However, even though PT. XYZ benefits from a cost perspective, this mismatch results in unpredictable uncertainty. So that this process does not always generate profits or have a good impact.

\section{Conclusion}

Based on the measurements and calculations as well as the discussion carried out, it can be concluded as follows:
1. The resulting DPO and DPMO were 0.377 and 382.508 , respectively, and were at the 1.7994 or 1.8 sigma level. A large number of defective products (below quality standards) are largely due to a decrease in the Conductivity Unit (CU). So that the effort made is to do Doping Stadis 450.

2. The inefficiency of the Doping Stadis 450 process will result in suboptimal use of the Stadis 450 . For this reason, the measurement of the decrease in the average CU value on the Avtur/Jet A-1 in the sales tank was carried out, the result was $6.4646 \mathrm{pS} / \mathrm{m}$ per day. This can then be a consideration in determining the target $\mathrm{CU}$ value to minimize waste and approach the optimal use of the Stadis 450 volume.

The inefficiency can be indicated by the presence of a final CU that exceeds the target $\mathrm{CU}$ value or does not even reach the target, with an average of $41.67 \mathrm{pS} / \mathrm{m}$. When viewed from a cost perspective, PT. XYZ benefits from the mismatch of the doping process of Rp. $13,524,894$. However, this advantage comes from an uncertain and unpredictable process. So that in certain conditions, losses are also possible. 


\section{References}

[1] Munro R A, Ramu G, and Zrymiak D J 2015 The Certified Six Sigma Green Belt Handbook 2nd Edition (Milwaukee: ASQ Quality Press) p 7

[2] Pochampally K K and Gupta S M 2014 Six Sigma Case Studies with Minitab ${ }^{\circledR}$ (Boca Raton: CRC Press) $\mathrm{p} 7$

[3] Prihastono E 2012 Pengendalian Proses Statistik untuk Meningkatkan Produktivitas dan Kualitas pada Industri DINAMIKA TEKNIK 6(2) 20-26

[4] The Council for Six Sigma Certification 2018 Six Sigma Master Black Belt Certification TRAINING MANUAL June 2018 Edition (Buffalo: The Council for Six Sigma Certification) $\mathrm{p} 12$

[5] The Council for Six Sigma Certification 2018 SIX SIGMA: A Complete Step-by-Step Guide July 2018 Edition (Buffalo: The Council for Six Sigma Certification) p 10 